\title{
A BRAF-Negative Classic Hairy Cell Leukemia Patient with Long- Lasting Complete Remission after Rituximab and Pentostatin
}

\author{
Rituksimab ve Pentostatin Sonrası Uzun Süreli Tam Remisyonda Olan BRAF-Negatif Klasik \\ Saçlı Hücreli Lösemi Hastası
}

(D) Alessandro Gozzetti1,2, (D) Vincenzo Sammartano2, (D) Francesca Bacchiarri2, (D) Donatella Raspadori 2, (D) Monica Bocchia1,2

1University of Siena, Hematology, Siena, Italy

To the Editor,

The BRAF gene is mutated (V600E) in more than $95 \%$ of classic hairy cell leukemia (HCLc) cases $[1,2,3]$, but cases have been reported of BRAF negativity in HCLc patients $[4,5,6,7]$. It has also been suggested to analyze mutations of exons 15 and 11 in the case of BRAF negativity [7]. Mutations in MAP2K1 were identified in cases of the wild-type BRAF gene [8,9]. Limited data are available about these patients. We report here a patient with HCLc who had a long-lasting response to rituximab and pentostatin treatment. A 51-year-old woman was referred for lymphocytosis and fatigue. Physical examination revealed splenomegaly $5 \mathrm{~cm}$ below the costal margin. Laboratory findings confirmed lymphocytosis with white blood cell (WBC) count of $17.64 \times 10^{3} / \mu \mathrm{L}$, hemoglobin $(\mathrm{Hb})$ of $11.4 \mathrm{~g} / \mathrm{dL}$, and platelet count of $187 \times 10^{3} / \mu \mathrm{L}$. A blood smear revealed $32 \%$ of cells with hairy features. Immunophenotyping of peripheral blood showed 45\% of cells to be CD5-, CD19+, CD20+, CD11C+, FMC7+, CD25+, CD103+, CD123+, and lambda-restricted. The bone marrow aspirate was a dry tap and the bone marrow biopsy confirmed hairy cell infiltration of $>90 \%$, TRAP+, DBA44+/-, ANXA $1+$. A computed tomography (CT) scan confirmed splenomegaly. IGHV status was mutated and showed $96.88 \%$ homology with IGHV3$7^{*} 01$ usage. Mutation analysis of TP53 performed by polymerase chain reaction and DNA direct sequencing of exons 2 through 10 revealed a wild-type status. Allele-specific PCR for BRAF V600E, T599I, V600M, and K601E at exon 15 and G464E, G464V, G466R，G466A，G466V，G466E，G469R，G469A，G469V，G469E， and V471F at exon 11 did not detect mutations. PCR and direct DNA Sanger sequencing of both exons 15 and 11 did not reveal mutations. A diagnosis of BRAF-negative HCLc was made. Due to the presence of fatigue in a relatively young woman with disease-related anemia, she was treated with cladribine (CD) at a total dose of $10 \mathrm{mg}$ daily for 5 days subcutaneously, but splenomegaly was still present $2 \mathrm{~cm}$ below the costal margin 4 months later, and hairy cells were still present at a rate of
$50 \%$ in bone marrow biopsy. After 10 months she developed severe neutropenia (WBC count $2.1 \times 10^{3} / \mu \mathrm{L}$, neutrophils $4 \%$, hairy cells $25 \%, \mathrm{Hb} 10.5 \mathrm{~g} / \mathrm{dL}$, platelets $142 \times 10^{3} / \mu \mathrm{L}$ ). Rituximab at $375 \mathrm{mg} / \mathrm{m}^{2}$ IV and pentostatin at $4 \mathrm{mg} / \mathrm{m}^{2}$ every 14 days were administered a total of eight times. Normalization of blood counts and absence of hairy cells was observed by bone marrow biopsy and flow cytometry 4 months later. The CT scan showed normal spleen diameters. At the last follow-up (78 months after therapy), the bone marrow aspirate and biopsy still confirmed complete recovery. Hematologic values were normal: WBC count $5.1 \times 10^{3} / \mu \mathrm{L}$, neutrophils $56 \%, \mathrm{Hb} 13.5 \mathrm{~g} / \mathrm{dL}$, and platelets $182 \times 10^{3} / \mu \mathrm{L}$. Splenic diffuse non-Hodgkin lymphoma could be excluded by the presence of TRAP+, ANXA1+, and CD123+ cells. Few BRAF-negative HCLc patients have been reported (Table 1), with 11/53 pretreated patients with HCLc in one study, without data related to response [4]. Another study reported 2 patients being BRAF-negative at exon 15, with one responsive to $C D$ and the other to splenectomy [5]. One study reported 1 patient negative at exon 15 and responsive to $C D$ [6]; another reported 3 patients negative at exon 15, two of whom showed

Table 1. BRAF wild-type HCLc cases reported in the current literature.

\begin{tabular}{|l|l|l|l|}
\hline & Exon 15 & Exon 11 & IGHV \\
\hline Xi et al. [4] & $11 / 53(21 \%)$ & Not studied & $5 / 11$ IGHV 4-34+ \\
\hline $\begin{array}{l}\text { Schnittger } \\
\text { et al. [5] }\end{array}$ & $2 / 117(1.7 \%)$ & Not studied & $2 / 2$ IGHV 4-34- \\
\hline $\begin{array}{l}\text { Langabeer } \\
\text { et al. [6] }\end{array}$ & 1 & Unmutated & Unknown \\
\hline $\begin{array}{l}\text { Tschernitz } \\
\text { et al. [7] }\end{array}$ & $3 / 24(12.5 \%)$ & $2 / 3$ mutated & Unknown \\
\hline $\begin{array}{l}\text { Hossain } \\
\text { et al. [10] }\end{array}$ & 1 & Not studied & Wild-type \\
\hline $\begin{array}{l}\text { Gozzetti et al. } \\
\text { (present study) }\end{array}$ & 1 & Unmutated & IGHV 4-34- \\
\hline
\end{tabular}


a mutation at exon 11 [7], and another patient responsive to $C D$ was reported [10]. More cases need to be studied.

Keywords: Hairy cell leukemia, $B R A F$

Anahtar Sözcükler: Saçlı hücreli lösemi, BRAF

Conflict of Interest: The authors declare no conflicts of interests.

\section{Authorship Contributions}

Design: A.G., V.S., M.B.; Data Collection or Processing: D.R.; Writing: A.G., F.B.

\section{Acknowledgments}

The authors thank the Hairy Cell Leukemia Foundation for support for patients and for arranging the annual experts meeting in order to share diagnostic and therapeutic information.

\section{HAIRY CELL LEUKEMIA}

This case was presented in part at the 2014 Hairy Cell Leukemia Foundation Annual Meeting in Houston, TX, USA.

\section{References}

1. Grever MR, Abdel-Wahab O, Andritsos LA, Banerji V, Barrientos J, Blachly JS, Call TG, Catovsky D, Dearden C, Demeter J, Else M, Forconi F, Gozzetti $A$, Ho AD, Johnston JB, Jones J, Juliusson G, Kraut E, Kreitman RJ, Larratt L, Lauria F, Lozanski G, Montserrat E, Parikh SA, Park JH, Polliack A, Quest GR, Rai KR, Ravandi F, Robak T, Saven A, Seymour JF, Tadmor T, Tallman MS, Tam C, Tiacci E, Troussard X, Zent CS, Zenz T, Zinzani PL, Falini B. Consensus guidelines for the diagnosis and management of patients with classic hairy cell leukemia. Blood 2017;129:553-560.
2. Tiacci $E$, Trifonov V, Schiavoni G, Holmes A, Kern W, Martelli MP, Pucciarini A, Bigerna B, Pacini R, Wells VA, Sportoletti P, Pettirossi V, Mannucci R, Elliott O, Liso A, Ambrosetti A, Pulsoni A, Forconi F, Trentin L, Semenzato G, Inghirami G, Capponi M, Di Raimondo F, Patti C, Arcaini L, Musto P, Pileri S, Haferlach C, Schnittger S, Pizzolo G, Foà R, Farinelli L, Haferlach T, Pasqualucci L, Rabadan R, Falini B. BRAF mutations in hairy-cell leukemia. N Engl J Med 2011;364:2305-2315.

3. Tiacci E, Schiavoni G, Martelli MP, Boveri E, Pacini R, Tabarrini A, Zibellini S, Santi A, Pettirossi V, Fortini E, Ascani S, Arcaini L, Inghirami G, Paulli M, Falini B . Constant activation of the RAF-MEK-ERK pathway as a diagnostic and therapeutic target in hairy cell leukemia. Haematologica 2013;98:635639 .

4. Xi L, Arons $E$, Navarro $W$, Calvo KR, Stetler-Stevenson $M$, Raffeld $M$, Kreitman RJ. Both variant and IGHV4-34-expressing hairy cell leukemia lack the BRAF V600E mutation. Blood 2012;119:3330-3332.

5. Schnittger $S$, Bacher U, Haferlach $T$, Wendland $N$, Ulke M, Dicker $F$, Grossmann V, Haferlach C, Kern W. Development and validation of a realtime quantification assay to detect and monitor BRAFV600E mutations in hairy cell leukemia. Blood 2012;119:3151-3154.

6. Langabeer SE, O'Brien D, McElligott AM, Lavin M, Browne PV. BRAF V600Enegative hairy cell leukaemia. Case Rep Hematol 2013;2013:513049.

7. Tschernitz $\mathrm{S}$, Flossbach $L$, Bonengel $M$, Roth $S$, Rosenwald $A$, Geissinger E. Alternative BRAF mutations in BRAF V600E-negative hairy cell leukaemias. Brit J Haematol 2014;165:529-533.

8. Waterfall JJ, Arons E, Walker RL, Pineda M, Roth L, Killian JK, Abaan OD, Davis SR, Kreitman RJ, Meltzer PS. High prevalence of MAP2K1 mutations in variant and IGHV4-34 expressing hairy-cell leukemia. Nat Genet 2014;46:810.

9. Maitre $E$, Bertrand $P$, Maingonnat C, Viailly PJ, Wiber M, Naguib D, Salaün V, Cornet E, Damaj G, Sola B, Jardin F, Troussard X. New generation sequencing of targeted genes in the classical and the variant form of hairy cell leukemia highlights mutations in epigenetic regulation genes. Oncotarget 2018;9:28866-28876.

10. Hossain A, Rafei H, Jariwala A, El-Shami K. A rare breed: Wild-type braf and ighv expression in a 29 year old lady with classical hairy cell leukemia. Leuk Res Rep 2017;7:20-22.

\section{CD9 Is a Very Helpful Marker for Discriminating AML-M3 from HLA-DR-Negative Non-M3 AML}

CD9 AML-M3 ve HLA-DR-Negatif M3 Dışı AML'nin Ayırt Edilmesinde Çok Yararlı Bir

\section{Belirteçtir}

(D) Esmaeil Shahabi Satlsar1,2, (D) Mohammad Mosleh33, (D) Mahdieh Mehrpouri4

1 Guilan University of Medical Sciences,School of Paramedical Sciences, Clinical Laboratory Sciences Department, Rasht, Iran

2Thakhte Tavous Pathobiology Laboratory, Flow Cytometry Department, Tehran, Iran

${ }^{3}$ Shahid Beheshti University of Medical Sciences, Hematology and Blood Banking Department, School of Paramedical Sciences, Tehran, Iran

${ }^{4}$ Alborz University of Medical Sciences, School of Paramedical Sciences Clinical Laboratory Sciences Department, Karaj, Iran 